Int. J. Morphol.,

36(3):915-920, 2018.

\title{
Post-Mortem Brain Weight Reference Range for a Select South African Population
}

\author{
Rango de Referencia del Peso Cerebral Post-Mortem \\ para una Población Sudafricana Seleccionada
}

S. Govender; L. Lazarus; B. Z. De Gama \& K. S. Satyapal

GOVENDER, S.;LAZARUS, L.; DE GAMA, B. Z \& SATYAPAL, K. S. Post-mortem brain weight reference ranges for a select South African population. Int. J. Morphol., 36(3):915-920, 2018.

SUMMARY: Human brain weight plays a significant role in clinical and forensic settings, as cause of death may affect brain weight; and may be used in the detection of abnormalities associated with neurological disorders. Brain weights are geography specific and incorrect reference ranges may hinder interpretation during clinical and autopsy settings. This study assessed the influence of age, sex and race on post-mortem brain weights of a select medico-legal population; to create a geographically relevant reference range of brain weights for the eThekwini region. Standard autopsy protocol and procedures, using the Ghon method of dissection were implemented on four hundred and eighty-one decedents. Decedents were obtained from a medico-legal state mortuary in the eThekwini region, KwaZulu-Natal, South Africa from June 2015 to March 2016. Black South African decedents comprised 83.6\% (402/481) of the sample population and whom reference ranges were formulated. Male decedents attained peak weight significantly earlier in the 11-20 year age interval, whereas female decedents in the 41-50 year age interval. However, no significance was observed between brain weight and age $(\mathrm{p}=0.799)$. Significant differences between sexes was noted, with mean male brains weighing significantly more $(137.69 \mathrm{~g}, \mathrm{p}<0.001)$. The mean brain weights were $1404.82 \pm 145.07 \mathrm{~g}$ and $1267.13 \pm 163.96 \mathrm{~g}$ in Black males and females, respectively. Post-mortem brain weights were predominantly of Black South Africans, with brain weights of both sexes comparably like those reported in the Northern hemisphere. However, brain weights attained peak weight at different age intervals, with variant brain weights between different racial groups within South Africa. Therefore, brain weight reference ranges may not be applicable to another geographic locality.

KEY WORDS: Brain Weight; Post-mortem; Reference range; South Africa.

\section{INTRODUCTION}

Brain weight reference ranges are a leading criterion used in a combination of clinical, pharmaceutical and medico-legal settings. The degree of atrophy or hypertrophy of the brain may be indicative of clinical anatomical abnormalities and even pathology (Singh et al., 2004; Kohli \& Aggarwal, 2006; Sheikhazadi et al., 2010).

At autopsy, an increase in brain weight suggests cerebral oedema but may be unaffected by visceral congestion and blood loss (Molina \& DiMaio, 2012, 2015). Changes in organ weight associated with aging may influence the consumption and toxicity of chemical compounds in children and adults and have been used to determine treatment related susceptibility (Haddad et al., 2001; Sellers et al., 2007). According to the WHO, neurological disorders are one of the significant risks posed to public health. The escalation of neurological disorders such as Alzheimer's, schizophrenia and autism, in recent years has brought about an intensified interest to the field of neuroscience (Brown et al., 1986; Aylward et al., 2002).

Demographic parameters such as the age, sex, and the racial ancestry of the individual has been noted to influence overall brain weight (Kohli \& Aggarwal; Sheikhazadi et al.; Prakash et al., 2013).

Variations of the age at which the peak weight of an organ is reached has been noted between populations, with gyral atrophy occurring at 60-years of age (Andersen et al., 2003). Age-related decline in the weight of the brain was attributed to the marked loss of myelinated nerve fibres in the aged (Marner et al., 2003). Despite age related changes and racial ancestry, the weight of the male brain averages between $120-150 \mathrm{~g}$ heavier than females and is 9-12\% larger 
(Chirachariyavej et al., 2006; Witelson et al., 2006; Kim et al., 2009; Molina \& DiMaio, 2012, 2015). Heavier brain weights in males can be attributed to differences in sexual hormonal regulation (Narongchai \& Narongchai, 2008). The influence of racial ancestry on brain weight is highly controversial and therefore, lacks consistency (Rushton \& Jensen, 2005). Autistic individuals present with brain overgrowth and macrocephaly, with individuals affected by Alzheimer's having physiologic decline in the weight of the brain and subsequent broadening of the lateral ventricles with increasing age (Skullerud, 1985; Sacco et al., 2015).

Forensic literature documents extensive data regarding Northern hemispheric populations (Ludwig, 2002; Connolly et al., 2016), with paucity of reference ranges for Sub-Saharan Africa and South Africa. Reference ranges are a leading criterion used during medico-legal autopsies and assist clinicians for the early diagnosis and improved prognosis of disorders. Consequently, incorrect reference ranges may lead to erroneous interpretation. Therefore, this study aimed to document post-mortem brain weights from a select medico-legal state mortuary in the eThekwini region and to determine the influence of parameters: age, sex and race on human brain weights- to provide a suitable reference range.

\section{MATERIAL AND METHOD}

Study design, Setting and Sample size. This observational case series study was undertaken at a preselected medicolegal state mortuary in the eThekwini region, KwaZuluNatal, South Africa. A consecutive series of 500 decedents were collected over the period June 2015 to March 2016. A sample size of 500 decedents were predetermined after taking into consideration statistical parameters at a $95 \%$ confidence level. The exclusion criteria were as follows: (i) decedents with an incomplete demographic profile, (ii) decedents with significant injury to surrounding tissue, and (iii) organs that were decomposed.

To remove any risk of infection, all individuals were required to use adequate protective gear as-well-as adherence to strict safety precautions. Eligible decedents were subjected to standard autopsy protocol and procedures- within $48 \mathrm{~h}$ after death. The autopsy procedure and organ removal were performed by the relevant forensic pathologist responsible for the autopsy. Retrieval using a steel receptacle and weighing of the brain was performed by the principal investigator- thereby limiting any bias in reporting. The Ghon method was the preferred method of dissection and entails the removal of the cervical, thoracic, abdominal and pelvic organs "en bloc" (Ludwig; Connolly et al.). Each brain was grossly examined for any pathology. Thereafter, the brain was weighed on an electronically calibrated scale, which was approved by the South African Bureau of Standards (SABS). The "wet weight" of all the brain samples was recorded. "Wet weight" refers to the state of the organ as soon as it is removed from the body cavity. Brain weight included the cerebral hemispheres, cerebellum, pons, and medulla; and was truncated using a scalpel at the start of the spinal cord.

Data collection and Statistical analysis. The data was collected in two parts: (i) documentation of decedent demographic characteristics from case reports- completed prior to autopsy, and (ii) the recording of brain weights (in grams). The following demographic data were available and utilised in this study, namely: Age (years), sex - males to females; and race (Black, Coloured, Indian and White South Africans).

The Statistical Package for Social Sciences (SPSS, Version 23.0) was used to assess the correlation/association of age, sex and race with brain weight. Statistical tests included: descriptive statistics to determine the mean and standard deviation of brain weights and was stratified by age, sex and race. Pearson product-moment correlation was used to assess correlation between brain weight and age and the Independent Sample T- test was used to compare the mean brain weights between sexes. Analysis of Variance (ANOVA) with Tukey HSD multiple adjustment comparison determined post hoc pairwise comparison of race groups. A p- value of less than 0.05 was considered statistically significant.

Ethical consideration and Approval. The study was completed in accordance with the Inquests Act No. 58 of 1959. Confidentiality of the decedents was ensured using randomised identifying numbers allocated to each decedent by the Forensic pathology services. Approval was granted by the Biomedical research ethics committee of the relevant institution (BE522/14) and Gate keeper permission by the Department of Health: Forensic pathology services (72/03/ 2015).

\section{RESULTS}

Total Sample Distribution. A total of four hundred and eight-one decedents $(n=481,96 \%)$ met the criteria for inclusion in this study and comprised of $377(78.3 \%)$ males and $104(21.6 \%)$ females; with a racial grouping of 402 $(83.6 \%)$ Black, 10 (2.1\%) Coloured, 42 (8.7\%) Indians 
and $27(5.6 \%)$ White South Africans. Mean brain weights of the total number of decedents $(n=481)$ is $1364.40 \pm 163.8 \mathrm{~g}$. Decedents were categorised into 10-year age intervals: 1-10, 11-20, 21-30, $31-40,41-50,51-60,61-70,71-80,81-90$.

Total Sample Parameters. The Pearson product-moment correlation test showed significant correlation with the age of the decedent and brain weight $(\mathrm{p}=0.020)$. However, the weight of the brain had a weak negative correlation with age $(r=-0.106)$, the negative correlation implied that after reaching peak weight- an increase in age results in minimal decreases in the weight of the brain. A comparison between male and female brains was made using the Independent Samples T-test. There was a significant difference between sexes ( $p<0.001)$, with the weight of male brains being heavier than that of female brains, by $148.06 \mathrm{~g}$ (Table I). A One-way Anova test was conducted to compare the influence of race on brain weights.
The test showed a significant difference between racial groups $(\mathrm{p}<0.001)$. In the eThekwini region, decedents of the White South African racial group, illustrated heavier brain weights in comparison to the other racial groups of the same region (Table I).

Black South African sample distribution. This study included 402 Black South African decedents, which comprised of $318(79.1 \%)$ males and 84 (20.9\%) females. The mean brain weight of Black male decedents was $1404.82 \pm 145.07 \mathrm{~g}$ and $1267.13 \pm 163.96 \mathrm{~g}$ in Black females. The difference in mean weights between sexes is $137.69 \mathrm{~g}$. Decedents were categorised into 10-year age intervals: 1-10, 11-20, 21-30, 31-40, 41-50, 51-60, $61-70,71-80,81-90$. The number of Black decedents per 10- year age interval is documented in Table II. Male decedents attained peak weight at the 11-20 year age interval, whereas the female decedents attained peak weight later at the 41-50 year age interval (Fig. 1). At every age interval, mean brain weights of male decedents were higher than females (Tables III and IV) (Figs. 1A, B).

Table II. Number of decedents observed per age interval (years).

\begin{tabular}{lcccccccccc}
\hline Age interval (years) & & $\mathbf{1}$ & $\mathbf{2}$ & $\mathbf{3}$ & $\mathbf{4}$ & $\mathbf{5}$ & $\mathbf{6}$ & $\mathbf{7}$ & $\mathbf{8}$ & $\mathbf{9}$ \\
& & $1-10$ & $11-20$ & $21-30$ & $31-40$ & $41-50$ & $51-60$ & $61-70$ & $71-80$ & $81-90$ \\
\hline Number of decedents & Male & 20 & 19 & 130 & 91 & 32 & 19 & 5 & 1 & 1 \\
& Female & 17 & 4 & 22 & 15 & 8 & 10 & 6 & 1 & 1 \\
\hline
\end{tabular}

Table III. Brain weight measure of spread in females per age interval.

\begin{tabular}{cccccc}
\hline Age Interval & Mean & Standard Deviation (SD) & Minimum & Maximum & Range \\
\hline 1 & 1220.18 & 223.01 & 625 & 1584 & 959 \\
2 & 1281.50 & 143.01 & 1128 & 1460 & 332 \\
3 & 1298.64 & 103.01 & 1134 & 1530 & 396 \\
4 & 1306.53 & 116.51 & 1098 & 1470 & 372 \\
5 & 1350.25 & 280.94 & 1116 & 1974 & 858 \\
6 & 1240.00 & 96.71 & 1114 & 1444 & 330 \\
7 & 1159.67 & 114.24 & 1026 & 1314 & 288 \\
8 & 1146.00 & - & 1146 & 1146 & - \\
9 & 1096.00 & - & 1096 & 1096 & - \\
\hline
\end{tabular}

Table IV. Brain weight measure of spread in males per age interval.

\begin{tabular}{cccccc}
\hline Age Interval & Mean & Standard Deviation (SD) & Minimum & Maximum & Range \\
\hline 1 & 1227.00 & 207.58 & 716 & 1600 & 884 \\
2 & 1470.32 & 151.89 & 1200 & 1778 & 578 \\
3 & 1423.42 & 122.16 & 954 & 1838 & 884 \\
4 & 1416.80 & 125.64 & 1110 & 1712 & 602 \\
5 & 1386.56 & 136.94 & 1098 & 1638 & 540 \\
6 & 1416.11 & 176.43 & 972 & 1834 & 862 \\
7 & 1332.40 & 85.46 & 1258 & 1464 & 206 \\
8 & 1152 & - & 1152 & 1152 & - \\
9 & 1192.00 & - & 1192 & 1192 & - \\
\hline
\end{tabular}



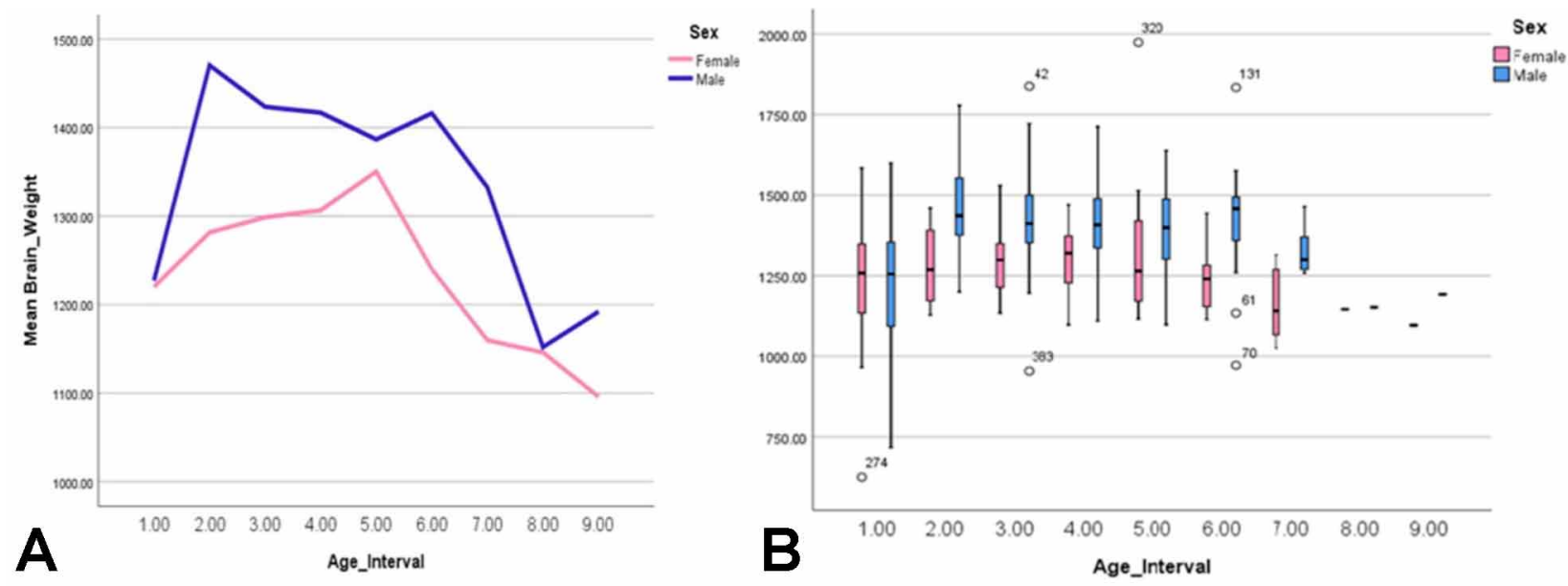

Fig. 1. Brain weight measures of spread between sexes: A- mean brain weights per age interval, B-Boxplot of spread.

\section{DISCUSSION}

This study observed the influence of demographic parameters viz. age, sex and race on human brain weights to establish a suitable reference range for the eThekwini region. Sub-Saharan Africa and South Africa lacks appropriate reference material regarding human brain weight, which plays an integral factor as the leading criterion considered in the interpretation of cause of death and the early diagnosis and prognosis of neurological disorders.

The overall results for the sample population showed that brain weight had a significant correlation with age and peak brain weights were reached early into adulthood (Table I). Mean brain weight of the present study was recorded as $1418.67 \pm 165.25$ g. Similarly, standard anatomical textbooks document the mean brain weight at $1500 \mathrm{~g}$ (Standring, 2008; Sinnatamby, 2011). It was observed that mean brain weights of male decedents were approximately $150 \mathrm{~g}$ heavier (Table I), concurring with previous studies (Chirachariyavej et al.; Witelson et al.; Molina \& DiMaio, 2012, 2015). This study yielded a significant difference between brain weight and the different racial groups under study. Results reflected White South African decedents having an overall higher brain weight than other racial groups observed (Table I). Racial disparity between populations has been noted in literature, (Table V). In comparison to Northern hemispheric data, values of brain weights of those with a similar ancestry shows discrepancies, as brain weights of the Indian South African population differs from those of the Indian continent (Table V). There is great controversy regarding race and therefore, an inconsistency of the results (Rushton \& Jensen).
The study comprised of predominantly Black South Africans, for whom reference ranges were created. Brain weights reached peak weight during early adulthood in black males, while female decedents reached peak weight much later (Tables III and IV). However, Prakash et al. documented peak weight at the 40-60 year age interval (Table V). Decline in the weight of the brain occurs faster in males than females (Witelson et al.). According to findings of the present study, as age increases the weight of the brain gradually decreases (Table I). Figure 1 illustrates increasing brain weights until peak, followed by a gradual linear decline in weight. Age-related changes in brain weights of Alzheimer's patients have been associated with a physiologic decline and broadening of the lateral ventricles (Skullerud). Consequently, results may be population dependent and therefore the need for geographic specific data. Furthermore, age -related decline was attributed to malnutrition and the marked loss of myelinated nerve fibres in the aged (Marner et al.). In medico-legal settings a comprehensive reference range is imperative as decedents dying of unnatural causes such as hanging and head injury, which shows a slight increase in brain weight (Tanna et al., 2011; Prakash et al.).

Despite age related changes and racial grouping, the weight of the black male brain was observed to be heavier (Table V), with black males of the present study weighing $137.69 \mathrm{~g}$ more. Brain weights differed between sexes of the same age (Fig. 1). Thus, concurring with previous studies, as they recorded an average difference between 120-150 g (Table V). However, studies by Davison Ankney (1992) and Rushton \& Jensen have observed 
Table V. Comparative data on brain weight between populations.

\begin{tabular}{lcccc}
\hline \multirow{2}{*}{ Author } & Population & Peak age interval (years) & \multicolumn{2}{c}{ Sex } \\
& & & Male & Female \\
\hline Singh et al. (2004) & India & $21-30$ & 1324.05 & 1195.73 \\
Narongchai \& Narongchai (2008) & Thailand & $<15$ & 1311 & 1170 \\
Kim et al. (2009) & Korea & - & 1423.39 & 1294.25 \\
Mathuramon et al. (2009) & Thailand & $15-20$ & 1330.62 & 1208.71 \\
Sheikhazadi et al. (2010) & Iran & 34 & 1322.3 & 1208.9 \\
Tanna et al. (201) & India & - & 1219.70 & 1156.20 \\
Molina and DiMaio (2012, 2015) & America & - & 1407 & 1233 \\
Prakash et al. (2013) & India & $40-60$ & 1115.51 & 1016.09 \\
Puttaswamy (2015) & India & $21-30$ & 1341.28 & 1210.25 \\
Connolly et al. (2016) & America & Males 19-21 & 1450 & 1340 \\
Present study & & Females 16-18 & & \\
& South Africa & Male 11-20 & 1404.82 & 1267.13 \\
\hline
\end{tabular}

differences of $100 \mathrm{~g}$. Narongchai \& Narongchai stated that differences in weight have been attributed to changes of sexual hormonal regulation. Due to the contrasting nature of brain weights, the findings of the present study may form part of a reference point for decedents of this region.

The study was limited as reference ranges could not be established for the other racial groups. The sample size was inadequate due to the eThekwini region being predominantly populated with Black South Africans. Additionally, decedents were obtained from a medico-legal state mortuary, consequently a history of the decedents underlying medical conditions and substance abuse could not be considered. For future studies, the authors wish to further collaborate with other medico-legal state mortuaries within South Africa, which would provide a better understanding of the population reference ranges.

\section{CONCLUSION}

Brain weights of the present study showed significance to the influencing parameters. In comparison to Northern hemispheric populations, brain weights for both sexes were comparably similar, with male brains weighing more. However, brain weights attained peak weight at varying intervals, with decedents of the White South African racial group having heavier brain weights than other racial groups under study. The present study also signifies variability of brain weights throughout the world. Brain weights in general are geographic specific and may not be applicable to that of another for accurate diagnosis of neurological disorders and for the interpretation of traumatic brain injury in medico-legal settings.

\section{ACKNOWLEDGEMENTS}

The authors gratefully acknowledge the assistance of the following parties: Dr. S.M. Aiyer, Acting Chief State Forensic Pathologist and the College of Health Sciences Research team, University of KwaZulu-Natal.

GOVENDER, S.;LAZARUS, L.; DE GAMA, B. Z \& SATYAPAL, K. S. Rango de referencia del peso cerebral postmortem para una población sudafricana seleccionada. Int. J. Morphol., 36(3):915-920, 2018.

RESUMEN: El peso del cerebro humano tiene un rol importante en los entornos clínicos y forenses, ya que la causa de la muerte puede afectar el peso del éste; además puede se puede usar en la detección de anomalías asociadas con trastornos neurológicos. Los pesos cerebrales son específicos de la geografía y rangos de referencia incorrectos pueden dificultar la interpretación en la clínica y la autopsia. Este estudio evaluó la influencia de la edad, el sexo y la raza en el peso cerebral post-mortem de una población médico-legal seleccionada; para crear un rango de referencia geográficamente relevante de pesos cerebrales para la región eThekwini. El protocolo y los procedimientos estándar de autopsia, utilizando el método de disección de Ghon, se implementaron en 481 cadáveres. Los cadáveres se obtuvieron de un depósito de cadáveres médico-legal en la región de eThekwini, KwaZulu-Natal, Sudáfrica, entre junio de 2015 a marzo de 2016. Los cadáveres, afro descendientes de Sudáfrica, comprendían el 83,6 \% (402/ 481) de la población de la muestra y se formularon los rangos de referencia. Los fallecidos masculinos alcanzaron el peso máximo significativamente más temprano en el intervalo de edad de 11-20 años, mientras que las mujeres fallecidas, correspondió al intervalo de edad de 41 años. Sin embargo, no se observó significación entre el peso del cerebro y la edad $(p=0,799)$. Se observaron diferencias significativas entre sexos, con cerebros masculinos medios que pesaban significativamente más $(137,69 \mathrm{~g}, \mathrm{p}<0,001)$. Los 
pesos cerebrales medios fueron $1404,82 \pm 145,07 \mathrm{~g} \mathrm{y}$ $1267,13 \pm 163,96 \mathrm{~g}$ en hombres y mujeres negros, respectivamente. Los pesos cerebrales post-mortem fueron predominantemente de sudafricanos negros, con pesos cerebrales de ambos sexos comparables a los reportados en el hemisferio norte. Sin embargo, los pesos cerebrales alcanzaron el peso máximo a diferentes intervalos de edad, con pesos cerebrales variables entre diferentes grupos raciales dentro de Sudáfrica. Por lo tanto, los rangos de referencia de peso del cerebro pueden no ser aplicables a otra localidad geográfica.

PAlabras ClaVe: Cerebro; Peso; Post-mortem; Rango de referencia; Sudáfrica.

\section{REFERENCES}

Andersen, B. B.; Gundersen, H. J. \& Pakkenberg, B. Aging of the human cerebellum: a stereological study. J. Comp. Neurol., 466(3):356-65, 2003.

Aylward, E. H.; Minshew, N. J.; Field, K.; Sparks, B. F. \& Singh, N. Effects of age on brain volume and head circumference in autism. Neurology, 59(2):175-83, 2002

Brown, R.; Colter, N.; Corsellis, J. A.; Crow, T. J.; Frith, C. D.; Jagoe, R.; Johnstone, E. C. \& Marsh, L. Postmortem evidence of structural brain changes in schizophrenia. Differences in brain weight, temporal horn area, and parahippocampal gyrus compared with affective disorder. Arch. Gen. Psychiatry, 43(1):36-42, 1986.

Chirachariyavej, T.; Ouyswat, K.; Sanggarnjanavanich, S.; Tiensuwan, M.; Peonim, V. \& Sirikulchayanonta, V. Normal internal organ weight of Thai adults correlated to body length and body weight. J. Med. Assoc. Thai., 89(10):1702-12, 2006.

Connolly, A. J.; Finkbeiner, W. E.; Ursell, P. C. \& Davis, R. L. Autopsy Pathology: A Manual and Atlas. Philadelphia, Elsevier, 2016.

Davison Ankney, C. Sex differences in relative brain size: The mismeasure of woman, too? J. Intell., 16(3-4):329-36, 1992.

Haddad, S.; Restieri, C. \& Krishnan, K. Characterization of age-related changes in body weight and organ weights from birth to adolescence in humans. J. Toxicol. Environ. Health A, 64(6):453-64, 2001.

Kim, Y. S.; Kim, D. I.; Cho, S. Y.; Kim, M. H.; Yang, K. M.; Lee, H. Y. \& Han, S. H. Statistical analysis for organ weights in Korean adult autopsies. Korean J. Anat., 42(4):219-24, 2009.

Kohli, A. \& Aggarwal, N. K. Normal organ weights in Indian adults. Med. Leg. Update, 6(2):49-52, 2006.

Ludwig, J. Handbook of Autopsy Practice. Totowa, Springer Science \& Business Media, 2002.

Marner, L.; Nyengaard, J. R.; Tang, Y. \& Pakkenberg, B. Marked loss of myelinated nerve fibers in the human brain with age. J. Comp. Neurol., 462(2):144-52, 2003.

Mathuramon, P.; Chirachariyavej, T.; Peonim, A. V. \& Rochanawutanon, M. Correlation of internal organ weight with body weight and length in normal Thai adults. J. Med. Assoc. Thai., 92(2):250-8, 2009.

Molina, D. K. \& DiMaio, V. J. Normal organ weights in men: part II-the brain, lungs, liver, spleen, and kidneys. Am. J. Forensic Med. Pathol., 33(4):368-72, 2012

Molina, D. K. \& DiMaio, V. J. Normal organ weights in women: Part II-the brain, lungs, liver, spleen, and kidneys. Am. J. Forensic Med. Pathol., 36(3):182-7, 2015.

Narongchai, P. \& Narongchai, S. Study of the normal internal organ weights in Thai population. J. Med. Assoc. Thai., 91(5):747-53, 2008.

Prakash, C.; Deopa, D. \& Thakkar, H. K. Study of internal organ weight and its correlation to body weight in kumaon region of Uttarakhand. $J$.
Indian Acad. Forensic Med., 35(1):29-32, 2013.

Puttaswamy. Weights of human organs at autopsy in Mandya zone Karnataka - A retrospective study. Int. Arch. Integr. Med., 2(9):70-6, 2015.

Rushton, J. P. \& Jensen, A. R. Thirty years of research on race differences in cognitive ability. Psychol. Public Policy Law, 11(2):235-94, 2005.

Sacco, R.; Gabriele, S. \& Persico, A. M. Head circumference and brain size in autism spectrum disorder: A systematic review and meta-analysis. Psychiatry Res., 234(2):239-51, 2015.

Sellers, R. S.; Morton, D.; Michael, B.; Roome, N.; Johnson, J. K.; Yano, B. L.; Perry, R. \& Schafer, K. Society of Toxicologic Pathology position paper: organ weight recommendations for toxicology studies. Toxicol. Pathol., 35(5):751-5, 2007.

Sheikhazadi, A.; Sadr, S. S.; Ghadyani, M. H.; Taheri, S. K.; Manouchehri, A. A.; Nazparvar, B.; Mehrpour, O. \& Ghorbani, M. Study of the normal internal organ weights in Tehran's population. J. Forensic Leg. Med., 17(2):78-83, 2010.

Singh, D.; Bansal, Y. S.; Sreenivas, M.; Pandey, A. N. \& Tyagi, S. Weights of human organs at autopsy in Chandigarh zone of North-West India. J. Indian Acad. Forensic Med., 26(3):97-9, 2004.

Sinnatamby, C. S. Last's Anatomy. Regional and Applied. Edinburgh, Churchill Livingstone/Elsevier, 2011.

Skullerud, K. Variations in the size of the human brain. Influence of age, sex, body length, body mass index, alcoholism, Alzheimer changes, and cerebral atherosclerosis. Acta Neurol. Scand. Suppl., 102:1-94, 1985.

Standring, S. Gray's Anatomy. The Anatomical Basis of Clinical Practice. $40^{\text {th }}$ ed. Edinburgh, Churchill Livingstone/Elsevier, 2008.

Tanna, J. A.; Patel, P. N. \& Kalele, S. D. Relation between organ weights and body weight in adult population of Bhavnagar Region- A postmortem study. J. Indian Acad. Forensic Med., 33(1):57-59, 2011.

Witelson, S. F.; Beresh, H. \& Kigar, D. L. Intelligence and brain size in 100 postmortem brains: sex, lateralization and age factors. Brain, 129(Pt. 2):386-98, 2006.

Corresponding author:

Professor K. S. Satyapal

Department of Clinical Anatomy

School of Laboratory Medicine and Medical Science

College of Health Sciences

University of KwaZulu-Natal

Private Bag X54001

Durban

4000

SOUTH AFRICA

Email: satyapalk@ukzn.ac.za

Received: 01-12-2017

Accepted: 10-04-2018 